ACTA UNIVERSITATIS LODZIENSIS

FOLIA LITTERARIA POLONICA 6(36) 2016

http://dx.doi.org/10.18778/1505-9057.36.06

Monika Bednarczuk*

\title{
Modernity and the Jewish Stigma. Julian Tuwim, Alfred Döblin and Kurt Tucholsky: Biographies and Work
}

According to the title of this collection: Tuwim bez końca (Endless Tuwim), I'd like to propose a "Central European" look at the work and life of Tuwim as seen from the perspective of his Jewish background. In this essay I will compare the Polish poet with German authors I have chosen to further investigate by means of their biographies, their views and the fields that Döblin, Tuwim and Tucholsky worked in ${ }^{1}$.

* Dr, e-mail: monika.bednarczuk@rub.de, Slavic Department / Lotman-Institute, Ruhr-University Bochum, 44780 Bochum, Germany.

${ }^{1}$ See J. Sawicka, Julian Tuwim, Wiedza Powszechna, Warsaw 1986, pp. 24-25; P. Matywiecki, Twarz Tuwima, W.A.B., Warsaw 2007, pp. 97-108, 120, 129-137. Some Polish authors knew about Tucholsky. Let us recall a fragment from Inge Bartsch by Konstanty I. Gałczyński (K.I. Gałczyński, Serwus, Madonna. Wiersze i poematy, edition II, Czytelnik, Warsaw 1987, pp. 64-65):

She was a redhead but not really - there was a certain flicker in her hair -

[...] she had some German flavour to her,

That accent in the word "Mond" - the moon... der Mond, im Monde...

$[\ldots]$

A simple story: I just came back to Poland...

Berlin... Berliiin... rain...

Frederic of iron pressed on my heart like indigestion...

Boredom - and suddenly a revelation!

A theatre! A small heart in the underground!

There goes a song: author: Kurt Tucholsky.

K.I. Gałczyński, Inge Bartsch

Neither Tucholsky nor Döblin are authors whose works are easy to translate. Polish readers can read Berlin Alexanderplatz by Döblin (see A. Döblin, Berlin Alexanderplatz. Dzieje Franciszka Biberkopfa, translated by I. Czermakow, foreword by S. Lichański, edition II, Warsaw 1979), and Tucholsky's novel Zamek Gripsholm (see K. Tucholsky, Zamek Gripsholm, translated by Z. Fonferko, PIW, Warsaw 1986), some satires, published mainly in the fifties (see K. Tucholsky, Ksiega pięciu szyderców, translated by J. Frühling, A. Dołęgowski, Compilation and preface by A. Marianowicz, Czytelnik, Warsaw 1955; moreover there are single pieces in anthologies - see Niemiecka satyra antyfaszystowska, compilation by A. Marianowicz, E.J. Osmańczyk, Czytelnik, Warsaw 1951; A. Marianowicz, Plamy na stoneczku. Wiersze, utwory estradowe szopki, parodie, fraszki, humoreski, przektady 1945-1956, PIW, Warsaw 1957), as well as chansons, translated for 
Such an approach seems justified by both the mutual relations of the mentioned aspects (biographies and work), as well as the fact that in the interwar period we often experience the vanishing of the boundary between life and art. That vanishing is in part done by those literary men (on the one hand they autoperform, on the other, they transfer literary or ideological matters from the artistic sphere into the practical domain and vice versa). That vanishing is also triggered by people around them (e.g. to discredit the rival as an artist or a person by using an argument of "racial" otherness). ${ }^{2}$

I see Tuwim as one of the brilliant authors of Jewish origin, who at a time of rising anti-Semitism and national socialism, painfully experienced the aftermath of their descent and exhibited special artistic and social sensitivity. It was developed by, among other things, the impact of the awareness of their own otherness, by their surprisingly similar family stories and the feeling of lacking (the lack of mother, father, love, money, recognition) that plagued them. They experienced that lacking even despite their apparently exciting lives and spectacular successes. Moreover, Tuwim like Döblin and Tucholsky, rejected Nazism and was a sceptical observer of how the left was becoming more and more totalitarian in the thirties, and, after the war, all of them saw their hopes for a better world disappear. ${ }^{3}$ They, too, felt not fully requited love for the cultures of the countries they were raised in.

The biographical and ideological connections manifested themselves in a number of ways in the life and work of Döblin (born in 1878), Tucholsky (1890) and Tuwim (1894) and were to a greater or lesser extent expressed by all three. Their importance became painfully clear in the face of the Holocaust. Tucholsky, called the "Cassandra of his epoch" died earlier, but he predicted it - he was, after all, one of the first people to be deprived of German citizenship after Hitler came to power. He could only watch from abroad the public burning of his texts in the square in front of the Berlin Opera and the imprisonment of his friend and colleague Carl von Ossietzky in $1933 .{ }^{4}$

performance (directed by Józef Skwarek in 1993, by Agnieszka Glińska in 2003 and interpreted by Krystyna Tkacz in 2012).

${ }^{2}$ K.A. Grimstad analyses that matter, Polsko-żydowskie gry kabaretowe, czyli Juliana Tuwima próba akulturacji, translated by M. and M. Lachman, "Teksty Drugie" 2003, issue 3, pp. 47-63.

${ }^{3}$ Tucholsky represented the moderate left in "Die Weltbühne", where appeals for a union between pacifists and communists against NSDAP were made. "Linkskurve", hostile towards unorthodox slogans, fought against, among others, Alfred Döblin and Kurt Tucholsky. See Cz. Madajczyk, Klerk czy intelektualista zaangażowany? Świat polityki wobec twórców kultury i naukowców europejskich w pierwszej połowie XX wieku. Panorama, Wydawnictwo Poznańskie, Poznan 1999, pp. 223-224. For Tuwim's political views and his literary and non-literary work see M. Urbanek, Tuwim. Wylękniony bluźnierca, Wydawnictwo Iskry, Warsaw 2013.

${ }^{4}$ Cz. Madajczyk, op. cit., pp. 224, 232, 496. Carl von Ossietzky first lands in court in the imperial era, also because of the text by Tucholsky published in "Die Weltbühne". The journalist died in 1938, after receiving the Nobel Peace Prize for 1935, which he didn't pick up due to Göring and Hitler's prohibition. More in: M. Hepp, Kurt Tucholsky, edition 3, Rowohlt, Reinbek 2004, pp. 134-136. 


\section{Childhood and youth: common experiences}

In the biographies of those three, family tragedies play an important role. Alfred Döblin suffered because of his father's double life and, finally, because he left for a younger woman ${ }^{5}$. His dominating mother, like her merchant brothers, was painfully practical, she despised the musical work and humanist passions of her husband, who was for Alfred the only kindred spirit at home ${ }^{6}$. The feeling of loneliness and otherness haunted Döblin all his life, despite his successes and affairs. In his only a few pages long Autobiography he complained about sleeplessness, lack of appetite, anxiety, compulsion for writing and doubts regarding his own talent. He also wrote about his existential fear and taming death ${ }^{7}$. Scholars attribute the specific structures of maleness in the prose of Döblin to his difficult childhood: sensitive protagonists - like the "frayed" by life Franz Biberkopf, who "swears to be an honest man"- allow themselves to be manipulated and even destroyed by ruthless patriarchs (an embodiment of this archetype being Reinhold from Berlin Alexanderplatz $)^{9}$. Unusual approaches to gender issues can also be found in the work of Bruno Schulz, Franz Kafka and other writers of Jewish descent.

The closest person for Tucholsky was also his father. Unfortunately, he died when Kurt was a teenager and the memories that the poet had from those last few years were traumatic. Alex Tucholsky was diagnosed with neurosyphilis and Kurt saw his mother as merciless (denying his dying father morphine), criticising and punishing her children, who almost hated her. For that reason, Tucholsky both sought tenderness and ran away from $\mathrm{it}^{10}$. The paradoxical feelings towards his mother and women in general can be seen in his, as we know from his letters, difficult relationships with his wife and her friends, as well as in the images of women in his lyrical and satirical pieces.

Tuwim's home was similarly not very rich and rather sad. His parents were not well matched in terms of their characters, fighting, they "hated the dullness of their lives", and his mother suffered from nervous disorders ${ }^{11}$. That complicated situation and the feeling of inferiority or even demonic otherness, which haunted Tuwim because of his birthmark, thoroughly analysed by Piotr Matywiecki in his

${ }^{5}$ A. Döblin, Doktor Döblin. Selbstbiographie (1918), H. Graber (ed.), Friedenauer Presse, Berlin 1970, pp. VIII-X.

${ }^{6}$ W.F. Scholler, Alfred Döblin. Eine Biographie, Carl Hanser Verlag, München 2011, pp. 11, 27-29, 33-36.

${ }^{7}$ A. Döblin, Doktor Döblin ..., pp. I-III.

${ }^{8}$ Idem, Berlin Alexanderplatz..., pp. 18-19.

${ }^{9}$ D. Voss, Ströme und Steine. Studien zur symbolischen Textur des Werkes von Alfred Döblin, Königshausen u. Neumann, Würzburg 2000, pp. 65, 180-181. See also W.F. Scholler, op. cit., pp. 33-36.

${ }^{10}$ M. Hepp, op. cit., pp. 10-13.

${ }^{11}$ J. Sawicka, op. cit., pp. 36, 38-39. 
study Tuwim's Face, may explain, at least in part, the depressive episodes that the poet experienced later in life.

Those biographies share a specifically divided childhood, spent in two places, which have different emotions related to them. Döblin and Tucholsky spent their first years in Szczecin, Tuwim lived in Lodz. The mother of the ten-year-old Döblin was forced to take her children to Berlin, which Alfred felt tough love for. Tucholsky arrived in Szczecin when he was seven years old ${ }^{12}$, but both of them believed that it was in Berlin that they consciously came to life. Döblin, "a Berliner with a faint idea about other places", would use the category of "rebirth", while Tucholsky would say:

As far as I remember I was born [...] as a worker of "Weltbühne" in Berlin. My ancestors - according to "Miezbacher Anzeiger" - sat on trees and picked their noses. ${ }^{13}$

In Warsaw Tuwim fulfills himself professionally, finds friends and admirers, but for Lodz, where he spent his childhood, he feels warmly, albeit ambivalently:

The Warsaw-Lodz train takes me in less than three hours from the period called "the age of maturity, the age of calamity" into childhood "pastoral angelical", so by some strange power my every visit to Lodz upends those few or few dozen years that separate me from my childhood and so on those terrible cobbles, among those terrible $[\ldots]$ houses, the time is turned $[\ldots]$ I'm connected to Lodz by the deepest sentiments $[\ldots]^{14}$

The cities of childhood remind them of home, more or less happy, but also of loyally submissive teachers, from whom the students escaped to simple pleasures (the meaningful wandering around the city) or to the world of fantasy, books and music. It's not an exaggeration to say that we can see there the trauma that triggered Döblin's, Tuwim's and Tucholsky's antipathy towards oppressive authority. At the same time the petit bourgeois background and the tendency for idealistic thinking, or, better, the social sensitivity, devoid of political fanaticism, protected the writers from radicalism.

All three had bad memories of early education and all three were self-taught when it came to literature. Döblin went to school in Berlin late - the moment it was decided that the responsibility to support their mother and siblings would be taken by the eldest brother. Alfred, as the most talented, was sent to secondary

${ }^{12}$ His parents were cousins: Tucholsky worked in Berlin Trade Society.

${ }^{13}$ A. Döblin, Doktor Döblin..., p. IV; W. Scholler, op. cit., p. 37; M. Hepp, op. cit., p. 7. Unless stated otherwise, translations are mine (M.B).

${ }^{14}$ J. Tuwim, Moje dzieciństwo w Lodzi (1925), in: Dzieła, vol. V: Pisma proza, Czytelnik, Warsaw 1964, pp. 13-14. 
school. He was, however, three years older than his classmates, felt bad about his glasses, stereotypically Semitic facial lines and intellectual differences: he avoided contacts with his classmates during breaks, pretended to be a grumbler and a loner, but still longed for a kindred spirit ${ }^{15}$. At the same time, he took great joy in reading, walking around the bustling city, watching and listening. When he was accepted to medical studies (a pragmatic choice of course), he still suffered from loneliness and an inferiority complex stemming from his ignorance in matters of sex and anatomy. While in his forties, preparing for his doctorate in Freiburg, famous for its beautiful landscapes, he wrote:

What use $[\ldots]$ is beautiful weather, mountains, forests and lakes? I hated them for many years $[\ldots]$ they made me suffer; it's as if I had walked into a big nickelodeon where no one plays, all tables are empty [...]. Bitterness - that's a proper word; that's how I still quite often feel about forest ${ }^{16}$.

Tucholsky found it difficult to adjust to the Prussian drill and patriotism, because he was innately contrary and distrustful towards what he was taught in class. His father had long foreseen the war and criticised the policy of the Emperor, which his son must have seen ${ }^{17}$. The poet's life in Berlin was also difficult, after all he would call it a prison in 1929. He passed his final exams as an extern, and most of his grades - even that from German - were just satisfactory. He also didn't finish his law studies (Berlin, Geneva, Jena), although at his third attempt he received a doctorate in law ${ }^{18}$. Berlin excites Tucholsky and provides him with opportunities for artistic development also because it irritates him.

Tuwim described the russification conducted by teachers in Lodz who treated students like recruits in barracks. He also had to face the slander he received from his friends for attending a free Russian state school which allowed access to further education. The only positive effect of taking such an education was his love for the Russian classics (Pushkin, Gogol) and brilliant linguistic intuition. His schooling was complemented by the streets of Lodz, odd objects he collected, pop culture and books. Tuwim said "I was [...] a cobblestone buff and a flaneur" because after classes there came the time of a ritual "shuttling from Andrzeja to Ceglana street and back", going to the theatre, cinema, the time of laughter, eavesdropping, blustering, singing couplets... ${ }^{19}$. Tuwim chose his studies - like many - for practical reasons (he chose law) and didn't complete them. A true poet's life.

15 A. Döblin, Doktor Döblin..., pp. VI-X; W. Scholler, op. cit., pp. 42-47.

${ }^{16}$ A. Döblin, Doktor Döblin..., p. VII.

${ }^{17}$ See K. Tucholsky, List mego ojca, translated by J. Frühling, in: Księga pięciu szyderców, pp. 138-139. That satire employs some autobiographical motifs.

${ }_{18}^{18}$ M. Hepp, op. cit., p. 13.

${ }^{19}$ J. Tuwim, Nauka szkolna i zainteresowania pozaszkolne (1936), in: Dzieła, vol. V, pp. 56-58. 


\section{Modernity: chameleonism, urbanisation, mass culture}

The biographies and works of Döblin, Tuwim and Tucholsky are good examples of the European modernity discourse with its paradoxes and heterogeneity. Modernity means great economic and social transformations (mobility, emancipation and uprooting), a new image of men and women (their psyche, their bodies, their sexuality), an invasion of the means of mass communication, development of metropolitan reality and new conditions for the life of literature. In parallel to emancipation, grows anti-Semitism and the importance of uniforming political movements (communism, fascism, national socialism). Modernism has its liberal and anti-liberal dimension ${ }^{20}$. It's born from discrepancy and hence its polyphonicity (expressionism, Dadaism, futurism, the interest in psychoanalysis and technology) and contradictions (the elevation of war and pacifism, ideological arguments and escapes into nature, aestheticization of violence and lyricism). The artistic and philosophical approaches to those issues in the first years after the Great War are obviously different from those presented later ${ }^{21}$.

All the mentioned elements of modernity can be found in the artistic and journalistic works of Döblin, Tuwim and Tucholsky. Let us begin with that aspect of modernity which assumes the possibility of self-fulfilment and of making individual decisions about the configuration of given aspects of life and work. And so art, being the main field of their work, goes in their case together with their journalistic work, additionally stimulated by the rules governing the mar$\mathrm{ket}^{22}$. That leads to a peculiar chameleonism, Proteus-like changeability, to wearing masks ${ }^{23}$.

Döblin, Tucholsky and Tuwim take on various roles for various reasons. Döblin is a doctor, a writer, a journalist, a clerk; Tucholsky is a lawyer, a musically talented member of the cabaret, a poet, a writer and a journalist; Tuwim is a poet, a translator, a man of the cabaret, a collector, a polemicist. All three enter the realm of mass culture, deal with various genres, mix styles: Döblin publishes medical treaties, an experimental novel (Berlin Alexanderplatz), an historical novel (Wallenstein), a futuristic one (Berge Meere und Giganten), a reportage (Reise in Polen), a parable (Die drei Sprünge des Wang-lun), an epos (Manas), a cantata (Das Wasser) and feuilletons. Tucholsky's literary output includes a variety

\footnotetext{
${ }^{20}$ I mean the conservative revolution with its slogans about (abrupt) return to nature and tradition.

${ }^{21}$ In the twenties Franz Kafka's works and Thomas Mann's The Magic Mountain are published. In Polish literature it's a rather "optimistic" period, contrary to the general atmosphere of the thirties. In the late twenties and early thirties Freud's (Civilization and Its Discontents), Mannheim's (Ideology and Utopia) and Ortega y Gasset's (The Revolt of the Masses) works are published.

${ }^{22}$ See J. Sawicka, op. cit., pp. 277, 281, 286.

${ }^{23}$ On Döblin as a master of change and "Proteus" see his biographer (W. Scholler, op. cit., p. 287).
} 
of poetic forms, a parody, a cabaret song, a satire and a feuilleton (Deutschland, Deutschland über alles), stories (Rheinsberg), a travel journal (Ein Pyrenäenbuch), a comedy (Christoph Kolumbus, 1932). Tuwim, just like them, creates various poetical forms, writes satires, songs, librettos, comedy sketches, feuilletons, reviews and a digressive poem.

The compared authors also shared using aliases and artistic masks. Döblin was for some time heavily reliant on his mother's and her brother's opinion and funding - as a doctor he didn't earn much and, after getting married, he had to (because of some regulations regarding medical practitioners and nurses) leave the hospital and open his own practice. Initially, he writes under a pen name for fear of the reaction of his family ${ }^{24}$, but after 1933 he does so for political reasons. Tuwim separates serious writing from entertainment art using a dozen pseudonyms: Roch Pekiński, Oldlen, Julin Wim, Dr Pietraszak, Twardzioch, Brzost, Old Ack, Schyzio-Frenik, suggesting the playful character of his writings. The range of emotions in the works of Tuwim seems to confirm the opinion of Józef Wittlin, who wrote about his friend as a man "predatory, yet gentle [...], full of tragic contradictions" 25 . Tucholsky, writing for "Weltbühne" and other magazines, artistic and daily, several texts a week, appears under at least four pen names, every one of which encodes a different personality: on political topics he writes as Ignaz Wrobel, feuilletons about life and theatrical reviews are signed by Peter Panter, frivolous texts are written by Theobald Tiger and for Kaspar Hauser the dominating mood is melancholy mixed with irony ${ }^{26}$. Different names revealed different aspects of personality. They enabled masquerading, the changing of roles, the multiplication of authors, but Tucholsky himself, who protected his fragile ego, knew that his literary strategy bore some traces of schizophrenia ${ }^{27}$.

At the turn of the XX century comes "ostentatious, planned [...] revalorisation of the city". A new lyric subject experiences urban "heteroglossia" (perceptional poetic as Elżbieta Rybicka calls it) and uncovers the aftermaths of modernisation (by employing the style of parable and social documentary) ${ }^{28}$. Döblin, Tucholsky and Tuwim empathise equally strongly with the processes of modernisation and are equally ambivalent towards them. The observation of a metropolis involves seeing new phenomena and applying new means of expression. Let us recall the poem To the critics ("I used to ride, dear gentleman, / On the front platform of the

${ }^{24}$ W. Scholler, op. cit., pp. 11, 88-99.

${ }^{25}$ J. Wittlin, Śmierć Tuwima, in: Orfeusz w piekle XX wieku, Instytut Literacki, Paris 1963, p. 557.

${ }^{26}$ M. Hepp, op. cit., pp. 28-32.

${ }^{27}$ H. Haarmann, Kurt Tucholsky: "Eine Treppe: Sprechen - Schreiben - Schweigen", in: H. Haarmann, E. Schütz, K. Siebenhaar, B. Sösemann, Berliner Profile, Fannei \& Walz, Berlin 1993, pp. 133-134.

${ }^{28}$ E. Rybicka, Modernizowanie miasta. Zarys problematyki urbanistycznej w nowoczesnej literaturze polskiej, Universitas, Cracow 2003, pp. 28, 94-96. 
tram! / The city penetrates me thoroughly!") or the pieces like Chrystus miasta (Urban Christ), Colloquium niedzielne na ulicy (Sunday colloquium in a street), Mieszkańcy (Dwellers), Do prostego człowieka (To the simple man), Bal w Operze (Ball at the opera) and Kwiaty polskie (Polish flowers). Eyes in the Big City by Tucholsky ${ }^{29}$ pertains to the problem of loneliness in a hurrying crowd. Other texts of the satirist are set in or are about urban railway stations or parks, cinemas, theatres, revues, and bars crowded with people looking for even fleeting closeness. There are also advertising columns, giving hope to some and causing fear in others or dizzying shop windows. Each of these pieces focuses on a different aspect of urbanisation. The variety of attitudes ranges from conformist criticism of the middle class to sympathy for the proletarian poverty, from recording the deepening cynicism of society to hyperbolic prophecies of the apocalypse. That variety and periodicity reflect the character of the metropolis while documentary and fiction, reports and staging complement each other.

We can find a number of examples of the fascination with modernity as well as its criticism in the novel Berliner Alexanderplatz. Döblin commented on Joyce's Ulysses, highlighted the intrusions of advertisements and mass media into literature and used those observations. After all he was an enthusiast of the theatre, radio and the cinema - he cooperated in creating a script for a radio play based on his opus magnum and in creating a film adaptation ${ }^{30}$. New means of communication were instruments which made it possible to reach a mass audience ${ }^{31}$.

In Döblin's most famous work we find the image of a slaughterhouse, an episode taking place in a madhouse, a failed attempt at staying honest. The pace, multidimensionality and poliphonicity of the metropolis and the fragility of the individual, all are expressed by different registers - the biblical style, journalistic (headlines, headwords, Biberkopf selling newspapers at one point), bureaucratic (adjurations, announcements), scientific (medical diagnoses) and the style of nursery rhymes, propaganda and Berlin dialect, dominating in the dialogues.

Tucholsky also noticed how exceptional urban jargon, especially the Berlin dialect was. The specific mixture of truculence and roughness was close to him $^{32}$. It is worth noting here that apocalyptic motifs and linguistic elements based on

${ }^{29}$ T. Tiger [K. Tucholsky], Augen in der Großstadt, first printing: "Arbeiter Illustrierte Zeitung” 1930, issue 11, p. 217.

${ }^{30}$ M. Reich-Ranicki, Sieben Wegbereiter. Schriftsteller des zwanzigsten Jahrhunderts, DVA, München 2002, pp. 145-146; W. Scholler, op. cit., pp. 259-262, 296, 327, 349-352.

${ }^{31}$ In the years 1926-1932 the number of radio receivers registered in Germany grew from one to four million. Radios and turntables became common in houses, restaurants, gardens, railway stations and at picnics. See I. Luba, Berlin. Szalone lata dwudzieste, nocne życie i sztuka, Carta Blanca, Warsaw 2013, p. 57.

${ }^{32}$ H. Haarmann, op. cit., p. 134. See also K.M. Eichinger, Kurt Tucholsky, die Stadt Berlin und die Dörfer. Regionale Sprachformen als Symptom, in: Tucholsky heute. Rückblick und Ausblick, I. Ackermann, K. Hübner (eds.), Iudicium, München 1991, pp. 211-240. 
the style of the Revelation to John stem from the "existential tension between deficit and completeness" 33 and they usually have more secular than religious connotations ${ }^{34}$. The above mentioned remarks seem to be true for all three artists: Berlin Alexanderplatz, Ball at the opera and a number of Tucholsky's pessimistic comments are symptoms of anxiety and dissatisfaction about the status quo.

The big city is determined in the sphere of morality by factors such as eroticism, alcohol and crime. For that reason a new type of character is created (a freebooter, a prostitute, a petty thief, a drunkard and a drunken artist). The range of characters present in Tuwim's work includes politicians, artists, and "ordinary" people, but also pimps, beggars, "idiots" and "morons". When it comes to eroticism, we should mention the Phallic song, A Page from Human History, Spring, Ball at the opera, Urban Christ and, the fragment of Polish flowers, inspired by Warsaw dialect, and recorded by Stefan "Wiech" Wiechecki, devoted to couples kissing in arbours and a "sweaty and panting [...] completely drunk" Burakoszczak from Czerniakowska, Walercia’s skivvy, and Józio Gwizdalski from Wolska street, who were being driven by the chauffeur "for some grass, beer, and music" 35 .

An example of that new type of character is Tucholsky's prostitute, just like the one from the Song about indifference, serving people from all social groups, apolitical and disdaining politics:

This thing is not for her

She doesn't like the sham -

Politics is a hooker

And a man is just a man

K. Tucholsky, Under a streetlamp ${ }^{36}$

New protagonists are a bunch of thieves and burglars lead by Pums together withb the satanic Reinhold and the prostitutes populating the novel Berlin Alexanderplatz. They are sensitive, struggling with everyday life, sometimes murdered, but never condemned: sexuality, on the one hand, appears in the novel in the context of the Whore of Babylon and, on the other, is devoid of any secrecy due to the ubiquitous phenomenon of women and men selling their bodies and the development of scientific discourse analysing that sphere of human life ${ }^{37}$. Also at

${ }^{33}$ K. Vondung, Die Apokalypse in Deutschland, dtv, München 1988, pp. 75-76.

${ }^{34}$ J. Brokoff, Die Apokalypse in der Weimarer Republik, Wilhelm Fink Verlag, München 2001, p. 170.

35 J. Tuwim, Dzieła, vol. II: Kwiaty polskie, Czytelnik, Warsaw 1955, p. 17.

${ }^{36}$ T. Tiger [K. Tucholsky], Das Lied von der Gleichgültigkeit, "Die Weltbühne" 1932, issue 1, p. 29. I use here the translation by Roman Kołakowski. I quote the fragments of Tucholsky's pieces as cited in a booklet added to the Krystyna Tkacz śpiewa Kurta Tucholsky'ego, VIP-Production \& Polskie Radio 2009, p. 10.

${ }^{37}$ See A. Döblin, Berlin Alexanderplatz..., p. 47. 
that time Berlin is the place where Magnus Hirschfeld, a precursor of sexology and an activist for homosexual rights, becomes very active. The new type of hero is also exemplified by the commoner Frank Biberkopf, the killer of his lover and an ex-convict, who gets the reader and the narrator to sympathise with him, even though - as one critic put it - he was the first lover in German literature to become the pimp of his fiancée ${ }^{38}$. His sisyphic drive for good, and the towering obstacles have, however, a parabolic dimension ${ }^{39}$. The motif of arguing with God and the world is also present in Tuwim's work, e.g. in this piece:

But remember, when I fall, my mishap

Oh, God, I'll throw it in your face and

Know this: I'll raise my two iron fists up,

I'll kindle my eyes, look at you and threaten!

\section{J. Tuwim, Prayer}

What the discussed artists have in common is also the motif of alcohol and meetings in more or less exclusive cafes. In Warsaw, just like in Berlin, cafes were real bastions of artistic and social groups. Discussions and trysts in the saloons of Berlin, just like "binging" out of despair or "drowning their sorrows" accompanied by drunken singing are all important elements of the most popular of Döblin's novels, who, incidentally, wrote his doctoral thesis on memory disorders, including the mechanism of confabulation in Korsakov's syndrome ${ }^{40}$.

As early as in book one of Berlin Alexanderplatz we can come across a "moody singer" looking for volunteers that would listen to her and pay for her "hit song", offering kisses to the one who would win the auction. Her best song isn't ambitious at all, but tells us something about the average quality of entertainment:

She puts on a top hat, with arms akimbo, swings her hips and screeches into his [Frank's] face: - What were you thinking, Theodore, when you winked at me yesterday? What did you want, Theodore, when you asked me out for dinner? - And sitting on Frank's lap, she puts a cigarette into his mouth, which she has taken out of his pocket. She looks into his eyes, dabs his ears with hers and whispers: - Do you know what nostalgia is? [...] Everything around us is so cold and empty. - She hums, stretches on the sofa and smokes $[\ldots]^{41}$.

${ }^{38}$ M. Reich-Ranicki, op. cit., p. 143.

${ }^{39}$ H. Scherer, Individuum und Kollektv in Döblins Roman "Berlin Alexanderplatz", in: Das literarische Leben in der Weimarer Republik, K. Bullivant (ed.), Cornelsen Verlag Scripto, Königstein 1978, pp. 147-151.

${ }^{40}$ W. Scholler, op. cit., p. 77.

${ }^{41}$ A. Döblin, Berlin Alexanderplatz..., pp. 48-49. 
In the interwar cabaret the figure of a drunken man, whose comments were a mixture of the absurd, melancholy and current affairs was quite popular ${ }^{42}$. Moreover the very language, the track of thought and the way of speaking of people under the influence of alcohol attracted a lot of attention. Tuwim treated this topic lightly in his Quarrel with a wife, while Tucholsky mocked the imagination intensified by alcohol:

The hock is not strong enough,

so I'll take one more sip

Of a good, yellow whiskey

[...]

As beautiful as in my dreams

You can't be

[...]

Oh, how much better is kissing, when

The woman is somewhere else than you are...!

And so, here's to you!

K. Tucholsky, Sauflied, ganz allein ${ }^{43}$

Tucholsky becomes famous as a satirist in Berlin quite early, mainly as a cooperator with Die Wespen cabaret (The wasps) ${ }^{44}$, an author of songs interpreted by stars of German popular culture (Paul Graetz, Rosa Valetti, Kate Kühl, Mady Christians, Wilhelm Bendow) and a reformer of the chanson genre. In articles published in "Die Weltbühne" in 1919 Die Kunst des Couplets and Politische Couplets the poet calls for a new cabaret song, intellectually ambitious and formally subtle, with a catchy refrain. He also expects its creator to know the language of the street and understand the language and emotions of a "small man" Tucholsky, critical of American and British hit songs, suggests that local songs, similar to Parisian chansons, should be created, and emphasises the role of satire,

${ }^{42}$ K. Riha, Moritat, Bänkelsang, Protestballade. Kabarett-Lyrik und engagiertes Lied in Deutschland, edition 2, edited and extended, Athenäum, Königstein 1979, pp. 11-113, 125, 97-119.

${ }^{43}$ T. Tiger [K. Tucholsky], Sauflied, ganz allein [Drunken song in complete loneliness], "Die Weltbühne" 1931, issue 19, p. 701.

${ }^{44}$ Similarly to Erich Kästner, Ernst Busch and Hans Eisler. Wasps wanted to reach the masses through performing in various places. Loosely cooperating artists created programmes based on erotic and political topics.

${ }^{45}$ I. Wrobel [K. Tucholsky], Die Kunst des Couplets, [reprint in:] Gesamtausgabe. Texte und Briefe, vol. 3: Texte 1919, Rowohlt Verlag, Reinbek 1999, pp. 398-401; idem, Politische Couplets, [reprint in:] Gesamtausgabe, vol. 3, pp. 152-155. More in: K. Riha, op. cit., pp. 97-119. See also V. Kühn, Eine unglückliche Liebe. Kurt Tucholsky und das Kabarett, in: Halb erotisch - halb politisch. Kabarett und Freundschaft bei Kurt Tucholsky, S. Oswalt (ed.), BIS, Oldenburg 2000, pp. 49-76. 
particularly political satire ${ }^{46}$. At that time cabarets sprang up like mushrooms - during the 1923/1924 season there were 150 just in Berlin ${ }^{47}$. Among them were elite as well as crass groups, those with political ambitions, as well as those that were just oriented toward profits from prostitution and the sale of alcohol.

Tuwim's contact with the work of popular culture was similar ${ }^{48}$. The Picador Quid Pro Quo was created, together with shorter-lived projects. Quid Pro Quo developed successfully (group performances, political farces, Jewish comic skits) and starred some of the most popular performers of the time (Zuza Pogorzelska, Mira Zimińska, Hanka Ordonówna, Adolf Dymsza). In the mid-twenties we observe the boom in revues, parodies, autoparodies (including those questioning the ethnic background of Tuwim). Marian Hemar and Julian Tuwim also use political satire, gossip, and the language and information from the press. They aim their work at mature audiences and, similarly to Tucholsky, dream of shaping not only tastes but also social-political awareness ${ }^{49}$.

Political texts are proposed to the public (allusions to the myth of the legions, more re-shuffling at the top and various radicalisms), moral satire (including satire on the topic of Polish-Jewish cultural differences) and excellent hits (Love will forgive all [Mitość Ci wszystko wybaczy] or At the first sign [Na pierwszy znak]). Tucholsky's work is dominated by satire made for the Prussian mentality, militarisation and fascism, sometimes dressed up as trivial statements, other times reaching for elements of macabre humour. Shopping 1919 (Zakupy 1919) is an example of the latter:

What to buy little Mikey

For Christmas?

$[\ldots]$

Should I give him a potty on wheels?

A moratorium maybe?

${ }^{46}$ P. Panther [K. Tucholsky], Cabaret-Kritik, in: Gesamtausgabe, vol. 11: Texte 1929, Rowohlt Verlag, Reinbek 2005, pp. 488-489; I. Wrobel [K. Tucholsky], Politische Satire, in: Gesamtausgabe, vol. 3, pp. 326-329; idem, Was darf die Satire, in: Gesamtausgabe, vol. 3, pp. 30-32.

${ }^{47}$ I. Luba, op. cit., p. 80.

${ }^{48}$ See A. Kuligowska-Korzeniewska, Roch Pekiński in "Różowy Słoń" - estradowe wystapienia Juliana Tuwima w Łodzi podczas Wielkiej Wojny, in: Julian Tuwim. Biografia. Twórczość. Recepcja, K. Ratajska, T. Cieślak (eds.), Wydawnictwo Uniwersytetu Łódzkiego, Lodz 2007, pp. 210-251; L. Ignaczak, Tuwimowski romans z piosenka, in: Julian Tuwim. Biografia..., pp. 252-268.

${ }^{49}$ K. Krukowski, Moja Warszawka, Filmowa Agencja Wydawnicza, Warsaw 1957; J. Sawicka, op. cit., pp. 287-302. T. Stępień analyses the matter and its context thoroughly in Kabaret Juliana Tuwima, Wydawnictwo "Śląsk", Katowice 1989. On the special role of artists of Jewish origin in interwar entertainment writes K.A. Grimstad, reminding us that "almost all Jewish cabaret artists were Poles of Jewish descent or Poles to a certain degree of Jewish origin" (K.A. Grimstad, op. cit., p. 53, footnote 17). Similar contributions were made by people of Jewish descent in the film industry. 
A fat piglet, round as a bun?

A doll crematory?

K. Tucholsky, Shopping $1919^{50}$

The other leitmotif is the antinomies of male-female relationships. In the pieces which problematize them, melancholy, irony and cynicism dominate: men are shown as chronically unfaithful, and women, although they complain of their callousness and trust breaking, are also on the lookout for adventure. Both sides tend lie to one another, but also desire various illusions; being alone causes pain, but a life together can be reminiscent of hell. Love, as Tucholsky sums it up, "is: fulfilment, a heavy load and medicine", while man remains an incomplete being, half-hearted, lacking. ${ }^{51}$ This pessimistic image was to some extent influenced by the post war loosening of morals and all that was brought on by the modernisation of society (anonymity, individualism), but Tucholsky's personal disillusionments and failures were also the source of these bitter afterthoughts ${ }^{52}$.

The first man is always a setback

True knowledge comes only

Somewhere between the second and third.

Then, you know. Well, knowledge does not fulfil

But when things are lacking, you take what you get

amen.

\section{K. Tucholsky, Die Frau spricht ${ }^{53}$}

${ }^{50}$ K. Tucholsky, Zakupy 1919, translated by L. Lewin, in: Księga pięciu szyderców, p. 157. There was a vocal example of changing the political slogan of the left "Schlagt die Faschisten, wo ihr sie trefft" (Fight the fascists wherever you meet them) into "Küßt die Faschisten, wo ihr sie trefft" (Kiss...) in Rosen auf den Weg gestreut (1931). The fragment of the mentioned satire translated by Stanisław Jerzy Lec (see K. Tucholsky, Ścielcie im róże pod stopy..., translated by St. J. Lec, in: Księga pięciu szyderców, p. 176) goes like this:

If in their rallies they instigate,

"yes - say - amen",

praise the whip! [...]

Kiss the fascists wherever you can!

K. Tucholsky, Ścielcie im róże pod stopy...

For more on Tucholsky's political foresight see E. Lämmert, "Sie haben alles gesehen...". Tucholskys Warnungen vor dem Nationalsozialismus, in: Tucholsky heute, pp. 71-104.

${ }^{51}$ T. Tiger [K. Tucholsky], Die Frau spricht [Kobieta mówi], "Die Weltbühne" 1929, issue 33, p. 248.

52 It is difficult to explain the number of songs and poems about marriage break-down (Ehekrach), unfulfilled dreams ( $O b$ es das wohl gibt), misunderstandings (Eine Frau spricht, Eine Frau denkt), disappointment (Sie zu ihm, Gefühle, Ich habe dir alle hingegeben), envy (Der andere Mann) and loneliness (Es is) only with the goal of entertaining the audience. Similar dilemmas are experienced by Döblin's protagonists and himself. Tuwim's image of a woman is complex, but much more positive - see K. Sidowska, Obraz kobiety w poezji Juliana Tuwima, in: Julian Tuwim. Biografia ..., pp. 111-129.

${ }^{53}$ T. Tiger [K. Tucholsky], Die Frau spricht, p. 248. 


\section{Modernity and the petite bourgeoisie, the Jewish diaspora}

Here I'd like to refer to the last point of my biographical and idealogical thoughts mainly the class and ethnic, as well as class and cultural complexities which are related to the aforementioned problems of a flirtation with mass culture. According to Wilfriend Scholler, the petit bourgeoisie is an "emblematic character of modernity" 54 . The petite bourgeoisie, which the authors I mentioned come from, encourages conformist attitudes (proof of these limitations can be found in the fact that Tuwim never published the full version of Ball at the Opera: he wanted to provoke, but ultimately censored himself). Moderation, typical of the petite bourgeoisie, allows for mitigation of social tensions and spreading specific ideas and goods: from books and mass entertainment to "Ford", as it was put in The Residents. On the other hand, the petite bourgeoisie way of preferring mediocrity and defined rules in life: materialistic, but not devoid of cultural ambition, is met with resistance from many people who stem from this social class: from Döblin, through Tuwim, to Enzesberger ${ }^{55}$. Bourgeoisie descent causes a dissonance - an artistically and philosophically prolific one.

The effect of this awareness is a kind of empathy for the "Christ of the city" and his entourage, (thieves, prostitutes, cut-throats), for the "mad kike", "unschooled friends", but it always comes down to a solidarity within particular boundaries, which one researcher of Tucholsky called "distinction and engagement". A member of the bourgeoisie, more or less familiar with the history of mankind, and more restrained in his/her political views when compared to representatives of descendants of the gentry (still forming Polish culture in the first decades of the twentieth century), knows that the spiritual or intellectual level of the masses will not rise overnight, and that the mass is as fascinating as it is dangerous. Hence the desire to suck the masses into their own, ideologically and artistically more sublimated world has to contain a dash of mistrust: slogans are passed to the masses by "someone [...] from the outside, someone intellectually superior, someone who, despite a pretence of fraternization, will keep their distance. Someone who advises rebellion but does not announce participation" 56 .

Döblin's element - as Marcel Reich-Ranicki proves - is conflict. He was a Jew, and was therefore irritated by Judaism, he was Prussian, so he criticized Prussia and Germany, regardless of their system. Döblin writes a lot (with an intent of causing

${ }^{54}$ W. Scholler, op. cit., p. 43.

${ }^{55}$ H.M. Enzensberger, Von der Unaufhaltsamkeit des Kleinbürgertums, "Kursbuch" 1976, issue 45, pp. 1-8. See H. Schilling, Kleinbürger. Mentalität und Lebensstil, Campus, Frankfurt a. M. 2003, pp. 217-224.

56 T. Makles, Wobec ojczyzn. O ojczyznach ziemskich i idealnych w twórczości Juliana Tuwima i Antoniego Stonimskiego, Wydawnictwo Uniwersytetu Śląskiego, Katowice 1987, p. 54. 
change!): articles, comments, lampoons on literature, philosophy, theatre, music, politics, economy, theology; this is quick, witty writing, and it proves the author's anti-authority temperament ${ }^{57}$, he did not respect politics, he tested his friends' patience and did not care about readers' preferences (Thomas Mann, who respected Döblin, ruled that very few people are capable of reading his friend's books cover to cover $^{58}$. In a way however, Döblin meets his mass audience halfway: in interviews, he popularizes a democratization of culture, and aware of the competition that other media are to literature, he prints Berlin Alexanderplatz in "Frankfurter Zeitung", and contributes to the creation of radio and film adaptations of his novel, having already borrowed innovative montage techniques from film ${ }^{59}$.

Tucholsky also provoked his audience, but he wanted to educated it, at least, through plays written for cabaret. The satirical text and photograph collage called Deutchland, Deutschland über alles (1929) ${ }^{60}$ appeared in a workers' publishing house. In his revolutionary writing, Tucholsky wrote of a class war, he reached for "applied lyric", he mixed pathos with melancholy and cheap humour, he rejected the "violence of money" 61 , but was aware of his own superiority. His wife once wrote in a letter:

To the depths of your soul you are a bourgeoisie, who wants to have peace of mind, and phenomenal is the fact that you write poems as though you yourself went through the misery of a proletarian. You would always be filled with terror when you would see your real advocates ${ }^{62}$.

${ }^{57}$ M. Reich-Ranicki, op. cit., pp. 131-135. We can find more on Döblin's wit and cheekiness in P. Lüth, Alfred Döblin als Arzt und Patient, Hippokrates Verlag, Stuttgart 1985, p. 49. In 1926 Thomas Mann suggested accepting Döblin to the Prussian Academy, an idea which faced a lot of resistance. A year later, Döblin, who was soon after accepted into the Academy, provoked even more aversion when he published an article casting into doubt the possibility of separating the role of a member of the academia (involving representation of certain ideas and styles) and that of an artist. See W. Scholler, op. cit., pp. 312-314.

${ }^{58}$ Ibidem, pp. 123, 136. In his seventies Döblin attacked subjectivism and the publicist style of the novel genre (even though he greatly contributed to its evolution) and blamed, among others, Mann and Goethe (ibidem, pp. 129-130).

${ }^{59}$ F. Schneider, Filmpalast, Varieté, Dichterzirkel. Massenkultur und literarische Elite in der Weimarer Republik, in: Literarische Moderne, R. Grimminger, J. Murašov, J. Stückrath (eds.), Rowohlt, Reinbek 1995, pp. 469-472.

${ }^{60}$ Deutschland, Deutschland über alles is a compilation of satiric commentaries, illustrated with photographs and press clippings (collages were made by John Heartfield, which was a pseudonym of Helmut Herzfeld). The book mocking the shortcomings of the German people stirred much controversy.

${ }^{61}$ T. Phelan, Mythologie und Allegorie. Selbstverständnis und satirische Strategie bei Kurt Tucholsky, in: Das literarische Leben..., pp. 115, 123-128.

${ }^{62}$ As cited in: J. Meyer, A. Bonitz, "Entlaufene Bürger". Kurt Tucholsky und die Seinen, Deutsche Schillergesellschaft, Marbach 1990, p. 303. Mary Gerold, as Tucholsky's fiancée and wife, addressed him as "Mr/He". 
Kurt Tucholsky repeatedly expressed his disappointment with modern culture: he asked the "honourable" audience: "are you really as daft / as they [...] / keep telling us...?" (To the audience), expressing his anger, but also hope for possibly a negative - answer from the audience; in Personal he sadly concluded that gossip sells best, and in the song Undress, Petronello ridiculed vulgar tastes at the same time diagnosing a phenomenon which would reach an alarming scale tens of years later ${ }^{63}$.

Tuwim, not unlike Tucholsky, starts his affair with mass culture quite early: in 1914 with $B i-B a-B o^{64}$. Just like the German cabaret playwright, he focuses on originality in combination with communication, which means he does not plan on giving into the audience's pressure. Inspired by Whitman, he discovers the common man, which is why Poetry reads: "I do not wish to lead you, / I will gladly squeeze into the crowd" ${ }^{\prime \prime}$, but the crowd fascinates and frightens him simultaneously, which is shown in Wiosna (written 1915, published 1918) with the crowd as a "wonderful and simple criminal" defeated by "houndish temptation" Compassion for ordinary people can be found in the ode To the simple man as well as other poems which are close to it in meaning, a counterweight to approaching the anonymous, lower class man with empathy is established in visions of phantasmatic, "terrifying bourgeoisie" (it is symptomatic that the bourgeoisie are excluded from the category of "simple people", manipulated by the elite, even though they too were to some extent misled by stories of "glory and frontier"). The overall distance which the artist has towards the masses and the bourgeoisie showed itself in a retreat into issues of poetry's creative material, the philosophy of language, artistic experiments ${ }^{67}$, metaphysics and moralizing.

As noted by Zygmunt Bauman, Jews are in a way predestined towards undertaking new forms of activity ${ }^{68}$. Peter Gay in the study Die Republik der Außenseiter (1970), said that just the prospect of being active in the social, cul-

${ }^{63}$ As evidence of the topicality of those remarks from a century ago, I'll recall the commentary of Zdzisław Pietrasik on the behaviour of Polish audiences in 2013, published recently on his blog: Z. Pietrasik, Julia, zdejmij majtki!, Widzi Mi Się. Blog Zdzisława Pietrasika, 29.11.2013, http:// pietrasik.blog.polityka.pl/2013/11/29/julia-zdejmij-majtki/ [accessed on: 1.12.2013].

64 J. Dunin, Bi-Ba-Bo i gdzie indziej, Wydawnictwo Łódzkie, Lodz 1966, p. 69.

65 J. Sawicka, op. cit., p. 53.

${ }^{66} \mathrm{~J}$. Tuwim, Wiersze wybrane, compilation by M. Głowiński, edition 4 extended, Ossolineum, Wroclaw 1986, pp. 16-17.

${ }^{67}$ Stowa we krwi (1926) and other poem collections are characterised, as shown by Jadwiga Sawicka (op. cit., pp. 108-113), modernisation of the lyrical monologue, introduction of dialogues and everyday situations, including vulgar and colloquial elements. There also appear Young Poland motifs (the will, power, a creative individual) and expressionist motivations resulting in the antinomy of the national and the human.

${ }^{68}$ A Jew as a symbol of "leaving the flock", "the archetype of nonconformism and heresy". Z. Bauman, Nowoczesność i Zagłada, translated by F. Jaszuński, Fundacja Kulturalna Masada, Warsaw 1991, pp. 68-69, 73-75. 
tural, and political life in the Weimar Republic had a mobilizing and bracing effect on them, which resulted in their large scale involvement in bold challenges ${ }^{69}$. The zeal of many representatives of the diaspora for action and a search for new ways of self-realization was visible in interwar Poland. Both of these republics had inefficient systems (Weimar struggled with economic and political crises, it was attacked from every side similarly to the Second Commonwealth, were longed for but still "defective" and causing intense conflict: from the murder of president Narutowicz, through 1926, to the Bereza Kartuska prison. However, these countries created better conditions for Jews to function: Jews could rightfully take part in politics and science; they could strive for superior positions. But precisely due to the fact that persons of Jewish descent sometimes advanced quite quickly, and allowed themselves to be known as, for example, loud reformers, conservative and nationalist circles would see them as promoters of "unfamiliar", unwanted ideas ${ }^{70}$.

Assimilation itself, however, while constituting the basis of further endeavours toward social and professional success, caused resistance among non-Jews, as well as among the diaspora ${ }^{71}$. The growing competition in the workplace, as well as political conflicts and economic crises, caused an increase in the popularity of conspiracy theories and caused anti-republican prejudices to correspond to anti-Semitic ones ${ }^{72}$, even though a relatively small number of Jews had a career, and despite the gap between assimilated and orthodox Jews, and that between the moderately well-off and poor Jews.

Contrasts within the diaspora strongly influenced the way it was viewed by Döblin, Tuwim and Tucholsky. Dissimilarities between the orthodox and assimilated communities, along with judeophobia which intensified in the thirties, agitated the internal conflicts of these artists as they caused, next to a general liking of traditional Jews, a feeling of alienation, antipathy and even disdain, and - and this is no less important - an ambivalence toward themselves. In the Manichean

${ }^{69}$ H.J. Schütz, Juden in der deutschen Literatur. Eine deutsch-jüdische Literaturgeschichte im Überblick, Piper, München-Zürich 1992, pp. 231, 248.

${ }^{70}$ See ibidem, pp. 248-249, 131. See also P. Gay, Die Republik der Aussenseiter. Geist und Kultur in der Weimarer Zeit, 1918-1933, translated by H. Lindemann, introduction by K.D. Bracher, S. Fischer Verlag, Frankfurt a. M. 1970 (see also P. Gay, Weimar Culture. The Outsider as Insider, W.W. Norton, New York-London 1968); H. Mayer, Außenseiter, Suhrkamp, Frankfurt 1975 (Polish edition: H. Mayer, Odmieńcy, translated by A. Kryczyńska, Muza, Warsaw 2005); E. Prokop-Janiec, Literatura i nacjonalizm, Universitas, Cracow 2004.

${ }^{71}$ The problem is thoroughly analysed by A. Landau-Czajka, "Syn będzie Lech...". Asymilacja Żydów w Polsce międzywojennej, Wydawnictwo Neriton \& Instytut Historii PAN, Warsaw 2006, pp. 23-121.

72 Jews constituted less than one percent of the entire population of Germany (in 1925 there were fewer than 500 thousand of them among 70 million Germans), and that number was falling due to a decrease in the number of births, popularity of mixed marriages and assimilation. Most of them belonged to the middle class. See H.J. Schütz, op. cit., p. 232. 
thought pattern of anti-Semites (but to be precise, in the thought pattern of many non-Jews), as noted by Jean-Paul Sartre, the Jewish personality contains a sort of "magical" element, and a man considered by others to be a Jew (although not necessarily by himself), "no matter how hard he tries, cannot change this personality" 73 . It is no accident that in the twenties and thirties, Heine becomes current. Tucholsky is even named the "Heine of the twentieth century. Heine lends Tucholsky and Tuwim his self-mockery, taunts at convention, duality (priest/clown dichotomy), as well as certain themes ${ }^{74}$. Döblin refers to him several times, admiring his ideological boldness, self-reliance in style, and non-orthodox religiousness, however, due to Heine's imperfect morality, he criticizes the idea of building a monument in his name ${ }^{75}$.

Heine and other German-Jewish authors share a love-hate relationship with Germany, and Tuwim shares an ambivalence towards the Poles who are succumbing to nationalism. The expression "hurt in his love for the fatherland", which originally referred to Tucholsky ${ }^{76}$, does a good job of describing the fate of all three of the presented artists - also due to the fact that that they wound up sharing Heine's fate: exiled, deep inside they remained unhappy without "their own" language and "their own" audience around them.

The phenomenon, dubbed "Jewish self-hatred" by Leonard Lessing (1930), and "selective anti-Semitism" by Gay, and "anti-Semitism as a cultural code" 77 by Shulamit Volkov, presents itself here in all its glory. Tuwim is not in touch with his Qahal, Döblin leaves his in $1912^{78}$, to convert to Catholicism in 1941, Tucholsky leaves Judaism in 1911, and is baptized as an evangelical several years later, but admits to atheism ${ }^{79}$. All of them feel citizens of the nation among which they live. They

${ }^{73}$ J.-P. Sartre, Rozważania o kwestii żydowskiej, translated by J. Lisowski, Futura Press, Warsaw 1992, pp. 41-42, 69. Knut A. Grimstad reaches a similar conclusion, showing the paradoxical situation of Tuwim, who, despite his efforts, is rejected by the "ethnic", because they are the ones who decide on the rules in the "game of identity" (K.A. Grimstad, op. cit., p. 62).

${ }^{74}$ See J. Sawicka, op. cit., pp. 60-61. The similarities between Tuwim's and Heine's poetry is brilliantly shown by Giovanna Tomassucci in a study included in this collection of essays.

${ }^{75}$ Ch. Bartscherer, "Der ungezogene Liebling der Grazien". Alfred Döblin und Heinrich Heine: Politische und religiöse Analogien in Leben und Werk, in: Alfred Döblin. Paradigms of Modernism, S. Davies, E. Schonfield (eds.), Walter de Gruyter, Berlin-New York 2009, pp. 193-198.

${ }^{76}$ Cz. Madajczyk, op. cit., pp. 224, 232.

${ }^{77}$ See S. Volkov, Pomyst na nowoczesność. Żydzi niemieccy w XIX i na poczatku XX w., translated by J. Górny, P. Pieńkowska, Wiedza Powszechna, Warsaw 2006, pp. 66-67.

${ }^{78}$ Although Alfred Döblin's mother was assimilated and much more pragmatic than her husband, unlike him she read Hebrew books. See W. Scholler, op. cit., pp. 24-29, 43.

79 A letter to Arnold Zweig of 15 December 1935, in: K. Tucholsky, Gesamtausgabe, vol. 21: Briefe 1935, Rowohlt Verlag, Reinbek 1997, p. 471. See M. Hepp, "Dieser Jude Tucholsky hat Deutschland, hat Westeuropa noch manches zu sagen". Einführung zur Tagung, in: Kurt Tucholsky und das Judentum, M. Hepp (ed.), in cooperation with: K. Erwentraut, R. Links, Bibliotheksund Informtionssystem der Universität Oldenburg, Oldenburg 1996, p. 9. 
share specific types of chauvinism with these nations. Tuwim dislikes Germans (and also discreetly distances himself from Soviet Russia, mocking the myth of Jew-commies and the Jewish martinet). Interestingly enough, he refers to Yiddish as a "Hebrew-German stew", stressing the Germanness of Jews! "[...] I had a sort of innate antipathy for the world's greatest race. I must have foreseen their Teutonic feats. My anti-Germanic viciousness during the great war was indescribable" Döblin went through a short "nationalist" phase, defending Germany in the press after a militarily unjustified attack by the Prussian army on a Gothic cathedral in Reims ${ }^{81}$. Tucholsky scolded Poland in comments beneath a cartoon drawing of lice in a Polish military cap, a man drowning in a latrine (which was meant to illustrate the system beyond the eastern border), as well as in Polnisches Hexenlied [The Polish witch song], in which the titled Polish witches sing a sinister song over a fire: "Our doing is rebellion and evil" ${ }^{2}$ - an agitation which the writer soon regretted.

Döblin, Tuwim and Tucholsky quickly get on the side of pacifism though, a stance for which they are often attacked. Their anti-war attitude is influenced by experiences from their youth. Images of Russian soldiers shooting at protesters in Lodz in 1905, dead bodies of fighters and soldiers, along with puddles of blood slowly getting covered with sand engraved themselves permanently in Tuwim's memory. Tuwim shows his empathy to both sides of the conflict: let us recall a fragment dedicated to the widow of a Russian officer, who is wronged just as the Polish widows are. She hates "everything, them and herself". Tuwim's "Childish 'Farbenlehre' (colour palette)" is dominated by shades of red ${ }^{83}$. Tucholsky - similarly to Tuwim - did not have to actually shoot at anyone during the First World War, but he did wind up at the front in Courland and Romania, where he held the function of librarian and edited a soldiers' magazine; in the end he despised war. Döblin, on the other hand, repeatedly came into contact with victims of war as an army doctor somewhere on the western front, and in 1919 his sister died from a grenade explosion in Berlin. Hence Tucholsky (in the twenties), and Döblin (in the thirties) are for German-French agreement and get involved in leftist initiatives $^{84}$. Tuwim was "a poet of things final, and [...] things first", but he was also "a child of its times" and commented on the problems of this particular time, how-

\footnotetext{
${ }^{80}$ J. Tuwim, Książki, Chopin i Inowłódz, in: Dzieła, vol. V, p. 69.

${ }^{81}$ W. Scholler, op. cit., p. 140.

${ }^{82}$ K. Tucholsky, Polnisches Hexenlied, in: Gesamtausgabe, vol. 4: Texte 1920, Rowohlt Verlag, Reinbek 1996, pp. 576-577. The piece was illustrated with an expressive drawing and published in the magazine "Pieron" 1920, issue 11.

${ }^{83}$ J. Tuwim, Moje dzieciństwo w Łodzi, in: Dzieła, vol. V, p. 24; idem, Wspomnienia, in: Dzieła, vol. V, p. 39; idem, Dzieła, vol. II: Kwiaty polskie, pp. 59-68.

${ }^{84}$ Döblin joins in 1924 the established by, among others, Albert Einstein and Ernst Rowohlt Society of Friends of the New Russia and the Group 1925, together with Bertold Brecht, Robert Musil and Joseph Roth, in order to defend the freedom of art and left-wing activists. He isn't, however, very active in their ranks. W. Scholler, op. cit., pp. 271, 288-289.
} 
ever vague his ideological and political stance, which was based on rationality and a humanitarian approach ${ }^{85}$. He despised violence, at first due to the influence of an expressionistic disgust for mass killing (Atak, Morte home), later, terrified by the crimes committed during the Second World War. So when in America, because he is an idealist, he dreams naively of a "modest but clean" "home" and of the "rule of good, wise people" 86 :

I believe that man will rebel against machine and a monstrous "slaughter of engines" will happen. I believe that in the renewed world, chiefs, führers, and dukes and other scoundrels of the sort will disappear, along with other vessels of godless hubris, and with them all those $[\ldots]$ "black falangas"

A tendency toward idealism is shared by the authors discussed here: Tucholsky stubbornly calls on people to respect the dignity of simple men in anti-war and anti-capitalist satire ${ }^{88}$, Döblin also notices the danger which the expanded machine of the state carries with it early on:

I am amazed at the great violence of that which calls itself the state. [...] It is the individual who suffers, lives and dies; he and his relationships exist, while masses and organizations, groups hiding behind abstractions, want to ridicule and belittle the human. While doing so, they retract into sublime anonymity borrowed from tyrants of the past. The singular person [...] is degraded, a slave. [...] A tender sentiment for the homeland, an attachment to family, a love for friends, for their own tribe - look at how all of this has been devoured by the state; look at what this monster has done to those things. ${ }^{89}$

Note, again, how paradoxical the mechanism of identification with Poland or Germany by these authors is: solidarity takes place in spite of experiencing

${ }^{85}$ J. Wittlin, op. cit., p. 560.

${ }^{86}$ J. Tuwim, Dzieła, vol. II: Kwiaty polskie, p. 105.

${ }^{87}$ Idem, Youth, 1940, in: Dzieła, vol. V, p. 141.

${ }^{88}$ See his pacifistic piece published in: K. Tucholsky, Księga pięciu szyderców: Zakupy 1919 (translated by L. Lewin, p. 157), Na co idq wasze podatki (translated by S.J. Lec, pp. 158-159), Rodzice (translated by A. Dołęgowski, p. 182), Po pięciu latach (translated by L. Lewin, p. 188), Wojna wojnie! (translated by S.J. Lec, pp. 189-191), Modlitwa za więźniów (translated by S.J. Lec, pp. 185-186) and his satires aimed at greedy industrialists and clerks. To mention just a few translated into Polish: Spokój i porządek (translated by L. Lewin, pp. 159-160), Wiluś i reprywatyzacja (translated by A. Dołęgowski, pp. 160-161), Tak nas urządzili (translated by A. Dołęgowski, p. 161), Wolna gospodarka (translated by S.J. Lec, pp. 163-164), Pracy dla bezrobotnych (translated by S.J. Lec, pp. 179-180), Start (translated by S.J. Lec, pp. 180-181).

${ }^{89}$ A. Döblin, Podróż po Polsce, translated by A. Wołkowicz, afterword by H. Grynberg, Wydawnictwo Literackie, Cracow 2000, p. 277. For more on Döblin's ambivalent attitude towards the state see H. Grynberg, Posłowie, in: A. Döblin, Podróż po Polsce, p. 314. 
anti-Semitism. Döblin has trouble finding a job as a doctor in 1905, and also later in the thirties ${ }^{90}$; during the interwar period, Tuwim is one of the nationalist press's favourites to attack (and he responds to these attacks with adequate humour) ${ }^{91}$ : Jewish ancestry, several pacifist pieces, and, ultimately, the envy of young radicals over the Skamandrites' popularity are triggers for aggression. Among those three authors the most severe attacks are aimed at Tucholsky as an advocated of non-orthodox left-wing politics and an enemy of authoritarian government - regardless of whether it would come from the people, or be built on religion. The conservative, nationalist, communist and Jewish press insult him, some members of the diaspora resent the way he ridicules their amicability and blame him directly for provoking anti-Semites. Tucholsky receives letters full of insults and threats ${ }^{92}$. The poet himself does not consider his Jewish ancestry to be some sort of flaw, and in one of his last letters he admits that he only met with judeophobia in the press, and not in real life ${ }^{93}$. An articulation of complex, bicultural identity takes place in these authors in differing ways, and has a different purpose depending on the historical and political contexts. A denial of one's ancestry is out of the question, although an interest in Christianity appears. When speaking of Döblin's, Tuwim's and Tucholsky's attitudes towards Jews and their own Jewishness, Döblin's expression "accent shift" becomes useful ${ }^{94}$.

Alfred Döblin's parents and relatives went to the synagogue only to celebrate the most important of holidays, they joked about their heritage and ate non-kosher foods which, by the way, sickened Döblin ${ }^{95}$. It was not until the Berlin pogrom at the beginning of the twenties that Döblin began taking the fate of Jews more seriously, and decided to leave for Poland in 1924. From that moment on, the diaspora

${ }^{90}$ P. Lüth, op. cit., pp. 15-16, 29.

${ }^{91}$ The aftermaths of those conflicts we can also find in Polish flowers. Let us recall the physical attacks on Antoni Słonimski and the priest Tadeusz Puder and verbal aggression of ND activists (J. Tuwim, Dzieła, vol. II: Kwiaty polskie, pp. 108-113). See e.g.: ibidem, pp. 112-113:

It just seethed and flashed:

A Jew, of a Jew, for Jews, the Jews, you Jew;

$(-------------)$

When experienced conmen

Bit into my calves.

J. Tuwim, Kwiaty polskie

${ }^{92}$ See M. Hepp, “Dieser Jude Tucholsky...”, pp. 11-18.

${ }^{93}$ A letter to A. Zweiga of 15 December 1935, pp. 470-478. See also W. Grab, Kurt Tucholsky und die Problematik des jüdischen Selbsthasses, in: Kurt Tucholsky und das Judentum, pp. 31-44.

${ }^{94}$ A. Döblin, Schriften zu Leben und Werk, compilation by E. Kleinschmidt, Walter-Verlag, Olten-Freiburg 1986, p. 62. As cited in: H. Kiesel, Alfred Döblins Verhältnis zum Judentum, in: Alfred Döblin - Judentum und Katholizismus, K. Sauerland (ed.), Duncker \& Humblot, Berlin 2010, p. 27.

${ }^{95}$ Ibidem, p. 28. 
in Central-Eastern Europe interested him greatly, and - although he felt distanced from Jewishness - he started to feel proud of his ancestry after visiting Vilnius and Góra Kalwaria (Poland). He noticed the depth of the religiousness of Eastern European Jews, who in spite of poverty, conflicts with other ethnic groups and the ridicule of Christians, manage to maintain integrity, a sense of self-worth and faith in the purpose of cultivating the traditions of the fathers ${ }^{96}$ :

I now see what side locks are, what a proud adornment. These men, youths, and boys, when they walk in their clean, black gaberdines, [...] they have a dreamlike, romantic appearance $[\ldots]$. Their faces take on a special kind of quiet and serious expression. Some gaze with an unusual freedom and pride. [...] what an impressive nation, these Jews. I did not know them until now, I thought that what I saw in Germany, these overworked individuals, merchants [...] slowly becoming overgrown with fat, agile intellectuals, $[\ldots]$ miserable, sensitive people, I thought that these were Jews. Now I see: these are detached entities, far from the core of the people which live on here. [...] What has happened in this seemingly culturally barren East? How everything here revolves around the spirit! [...] Spirit binds not a thin layer of a nation, but an entire mass $^{97}$.

Besides "anaemically pale" Jews, he met those from which in a metaphorical and literal sense "a great endurance and spiritual strength flows" time, Döblin rejected Zionism ${ }^{99}$. In his works, Jüdische Erneuerung (1933) and Flucht und Sammlung des Judenvolks (1935), which he published in Amsterdam, he popularized either assimilation, or autonomy of the diaspora. He spoke out about the future of the diaspora, he studied Yiddish, but doubted the self-preserving instinct of - in his conviction overly individualistic - Jews ${ }^{100}$. Note, that during the Second World War, Alfred Döblin lost his brother (in a concentration camp), his son (in the army), and his sister in law (during the eliminations of the terminally and mentally ill from hospitals) ${ }^{101}$.

${ }^{96}$ Döblin's opinion of orthodox Jews was a bit exaggerated: "I know that those enlightened gentlemen will say. They laugh at 'dark primitives', [...] are ashamed of them. [...] Me myself, not an enlightened man nor to the commonalty, [...] to me those 'enlightened' in dirty cuffs on their forever gesticulating hands, in indented top hats [...] look similar to Blacks parading in glass beads, a gift from sailors. How poor, [...] without dignity nor soul is the West, which gave them those cuffs; but how can they know about it" (A. Döblin, Podróż po Polsce, p. 221).

${ }^{97}$ Ibidem, pp. 91, 121. For more on the spiritual dimension of that journey see M. Jäger, Autobiographie und Geschichte. Wilhelm Dilthey, Georg Misch, Karl Löwith, Gottfried Benn, Alfred Döblin, J.B. Metzler, Stuttgart 1995, pp. 281-350.

98 See A. Döblin, Podróż po Polsce, pp. 90, 293.

${ }^{99}$ Ibidem, p. 150.

${ }^{100}$ H. Kiesel, op. cit., p. 29.

${ }^{101}$ W. Scholler, op. cit., pp. 25, 485. 
Tucholsky felt that he was a German, and a European, but he did not find his home in any of the countries he lived $\mathrm{in}^{102}$. Despite the pretence of "having forgotten", he did not erase the stigma of his own Jewishness from his consciousness ${ }^{103}$. As proof, we have a letter he wrote to Arnold Zweig, in which he confesses that he has hated rabbis ever since he was young, but it was the passiveness of Jews which irritated him most: their emancipation took place, in his mind, thanks to the French Revolution, Palestine was a British colony in which Jews were assigned a defined role, and he thought of the German Jews as "cowards", absorbed, to their own peril, solely by "business". Jews were, therefore, defeated, and the "ghetto is not an effect [...] but a fate" 104 . The writer's internal conflicts manifested themselves in his statements, considered by some critics as anti-Semitic, as was the case with Mister Wendriner's Monologues, which was published under the pseudonym Peter Panther, and talks about the mentality of the Jewish Bourgeoisie $^{105}$. Here is an excerpt from Mister Wendriner under a dictatorship:

I met with my trade correspondent here, the one from Rome. He told me that in comparison to what is going on there, what we have here is a free paradise. You too have a yellow identification card? And we both do indeed. What, ten years? I've lived in Berlin for over twenty; I received mine right away, no problems at all. [...] - Take a closer look at this dark individual, here, below us! Surely a Jew from the East... You know, when it comes to those like him, anti-Semitism is truly a justified thing. [...] What an odious character! ${ }^{106}$.

Unlike German Jews, who often self-identified as Germans, Polish Jews, despite cultural assimilation, did not cut themselves off from their roots. As Anna Landau-Czajka shows us, during the interwar period, assimilated Polish Jews "did not have one clearly defined cultural identity"107. Tuwim's statements confirm her conclusions: the poet feels that he is a Pole, but does not

${ }^{102}$ Zob. F. Hackert, Wo ist man zu Hause? Vom Unbehagen und vom Harmoniegefühl des Kurt Tucholsky, in: Halb erotisch - halb politisch, pp. 143-166.

103 Tucholsky knew Kafka in person and they shared a mutual respect. Kafka almost immediately saw in him - he noted it in his diary - a spiritual brother. See M. Hepp, op. cit., pp. 22-26. Tucholsky wrote reviews of Kafka's works.

${ }^{104}$ A letter to A. Zweig of 15 December 1935, p. 472.

105 G. di Stefano, Die monologe des Herrn Wendriner - ein Fall von jüdischem Selbsthass?, in: Kurt Tucholsky und das Judentum, pp. 113-136; G. Kunert, Wenn Herr Wendriner noch lebte..., in: Tucholsky heute, pp. 47-53.

${ }^{106}$ K. Tucholsky, Pan Wendriner pod rzadami dyktatury, translated by J. Frühling, in: Księga pięciu szyderców, pp. 108-113. The poet also mocked anti-Semitism, e.g. in Piosenka starogermańska (K. Tucholsky, Księga pięciu szyderców, pp. 211-212).

${ }^{107}$ A. Landau-Czajka, op. cit., pp. 157. See also K.A. Grimstad, op. cit. 
deny his ancestry ${ }^{108}$. When responding to nationalist journalists, he stresses the love which his mother, grandmother and sister have for the Polish language (he proves the point by talking about three generations of women, because they were the ones who sought to Polonize their offspring $)^{109}$, as well as his grandfather's contribution as the printer of the first Polish magazine in Lodz. He points to his own praise for Polish music and literature:

And when sometimes anti-Semitic bores advise me [...], to write in Jewish (Mr. Jan Rembieliński encouraged me [...] in "the Nationalist Mindset", to clothe myself in Gaberdine and grow sidelocks $[\ldots])$, when $[\ldots]$ they encourage me to return to (?) the ghetto

To the ghetto, I cannot help but feel like [...] informing them, that my grandparents were already absent from the ghetto, and that I cannot write in the Jewish language because I neither know it, nor have I known it [...]. Polish was the language spoken in our family [...]. If I return anywhere, I will return to Poland, and if any future government of theirs throws me out, the one which comes after will give me a return visa. [...] J.T., a Polish poet ${ }^{110}$.

The orthodox Jews, especially those living in Poland, but parallelly to Polish culture, without a will to get to know it better, felt foreign to Tuwim, one could even say he felt a dislike toward them. The same was the case with factory owners and bankers as they were people who had values entirely different from his:

And a whole lot of these black, Jewish "uniforms". Their wearers use a monstrous, harking speech [...] I was, am and will be an opponent of these uniformed bearded men $[\ldots]$ and $[\ldots]$ their crippling of the Polish language. It is about time, gentlemen, to trim the long-skirted caftans [...], and also to learn respect for the language of the people among which you live.

$[\ldots]$

When the factories in Lodz receive some larger order, [...] lilacs bloom, nightingales tweet in Helenów, mud sparkles with all the colours of the spectrum, and the lethargic Lodzermensches become Übermensches, regaining [...] liveliness to their gaze, sharpness to their thoughts. [...] Greenbergs, Greenfields, Greensteins and Golbergs hop out of cabs, they run around the city as though possessed, they hop out of cabs, $[\ldots]$ make phone calls, jot things down, send telegraphs $[\ldots]^{111}$.

108 See H. Kowalska, Problem tożsamości narodowej w twórczości Juliana Tuwima, in: Pisarze polsko-żydowscy XX wieku. Przybliżenia, M. Dąbrowski, A. Molisak (eds.), Dom Wydawniczy Elipsa, Warsaw 2006, pp. 358-372.

${ }^{109}$ See A. Landau-Czajka, op. cit., pp. 184-193.

${ }^{110}$ J. Tuwim, Książki..., p. 63.

${ }^{111}$ Idem, Wspomnienia o Łodzi [1934], in: Dzieła, vol. V, pp. 34-36. 
He repeatedly publishes similar statements during the interwar period. At the same time - untrusting of collective phantasms and despising ideological blindness - he mocks the myth of the Jew-commies, he mocks the "racially" motivated attacks he receives and the stereotypical ideas about Jewish mentality ${ }^{112}$. However, when, after the Holocaust, he sees empty cities and his mother's grave, he will write his manifesto We, the Polish Jews, in which he reaches for desperate tones from the Book of Job and the prophetic writings of the Hebrew Bible. He will then identify with all the members of the diaspora, the assimilated Polonized ones, and the orthodox ones:

We Abies, we Kikes, we Sheenies whose names and nicknames will someday exceed in dignity those of Achilles, [...] and Richard Coeur-de-Lion.

We, once more in the catacombs, [...] under Warsaw pavements, splashing in the stink of sewers $[\ldots]$

We Jobs, we Niobes, mourning the loss of hundreds of thousands of our Jewish Urszulkas.

We, History's most glorious heap of bloody manure with which we have fertilized the Polish soil $[\ldots]^{113}$.

The moving phrases of the manifesto do an excellent job of summing up the creative work and social and political activity of authors of Jewish descent, who happened to live in Central Europe in the first decades of the twentieth century: they enriched, in the deepest sense of the word, the culture of the societies of they were a part, often paying a high price for their ancestry - for this "stigma", which in this period of raving anti-Semitism could not be erased or covered by any contribution made toward Polish or German culture and literature. The love that Jewish authors had for Poland or Germany remained rather unrequited ${ }^{114}$.

\section{Bibliography}

Alfred Döblin - Judentum und Katholizismus, K. Sauerland (ed.), Duncker \& Humblot, Berlin 2010. Alfred Döblin. Paradigms of Modernism, S. Davies, E. Schonfield (eds.), Walter de Gruyter, Berlin-New York 2009.

112 K.A. Grimstad, op. cit.

113 J. Tuwim, My, Żydzi polscy..., compilation and preface by Ch. Szmeruk, Fundacja Shalom, Warsaw 1993, p. 19. The manifesto is also available on-line - see, e.g. http://www. zydziwpolsce. edu.pl/biblioteka/zrodla/r1_1.html [accessed on: 19.11.2013].

${ }^{114}$ For more, see the classic dissertation by Artur Sandauer, O sytuacji pisarza polskiego pochodzenia żydowskiego w XX wieku: rzecz, która nie ja powinienem byt napisać, Czytelnik, Warsaw 1982. See also A. Elon, Bez wzajemności. Żydzi-Niemcy 1743-1933, translated by K. Bratkowska, A. Geller, Nisza, Warsaw 2012. 
Bartscherer Christoph, "Der ungezogene Liebling der Grazien". Alfred Döblin und Heinrich Heine: Politische und religiöse Analogien in Leben und Werk, in: Alfred Döblin. Paradigms of Modernism, S. Davies, E. Schonfield, Walter de Gruyter (eds.), Berlin-New York 2009.

Bauman Zygmunt, Nowoczesność i Zagłada, translated by. F. Jaszuński, Fundacja Kulturalna Masada, Warsaw 1991.

Brokoff Jürgen, Die Apokalypse in der Weimarer Republik, Wilhelm Fink Verlag, München 2001.

Das literarische Leben in der Weimarer Republik, K. Bullivant (ed.), Cornelsen Verlag Scripto, Königstein 1978.

Döblin Alfred, Berlin Alexanderplatz. Dzieje Franciszka Biberkopfa, translated by I.C. Zermakowa, preface by S. Lichański, ed. II, Czytelnik, Warsaw 1979.

Döblin Alfred, Doktor Döblin. Selbstbiographie (1918), H. Graber (ed.), Friedenauer Presse, Berlin 1970.

Döblin Alfred, Podróż po Polsce, translated by A. Wołkowicz, afterword by H. Grynberg, Wydawnictwo Literackie, Cracow 2000.

Döblin Alfred, Schriften zu Leben und Werk, E. Kleinschmidt (ed.), Walter-Verlag, Olten-Freiburg 1986.

Dunin Janusz, Bi-Ba-Bo i gdzie indziej, Wydawnictwo Łódzkie, Lodz 1966.

Eichinger Kurt M., Kurt Tucholsky, die Stadt Berlin und die Dörfer. Regionale Sprachformen als Symptom, in: Tucholsky heute. Rückblick und Ausblick, I. Ackermann (ed.), K. Hübner, Iudicium, München 1991.

Elon Amos, Bez wzajemności. Żydzi-Niemcy 1743-1933, translated by K. Bratkowska, A. Geller, Nisza, Warsaw 2012.

Enzensberger Hans Magnus, Von der Unaufhaltsamkeit des Kleinbürgertums, "Kursbuch” 1976, issue 45.

Gałczyński Konstanty Ildefons, Inge Bartsch, in: Serwus, Madonna. Wiersze i poematy, ed. II, Czytelnik, Warsaw 1987.

Gay Peter, Die Republik der Aussenseiter. Geist und Kultur in der Weimarer Zeit, 1918-1933, translated by H. Lindemann, preface by K.D. Bracher, S. Fischer Verlag, Frankfurt a.M. 1970.

Gay Peter, Weimar Culture. The Outsider as Insider, W.W. Norton, New York-London 1968.

Grab Walter, Kurt Tucholsky und die Problematik des jüdischen Selbsthasses, in: Kurt Tucholsky und das Judentum, M. Hepp, in cooperation with: K. Erwentraut, R. Links, Bibliotheks und Informtionssystem der Universität Oldenburg, Oldenburg 1996.

Grimstad Knut Andreas, Polsko-żydowskie gry kabaretowe, czyli Juliana Tuwima próba akulturacji, translated by M. and M. Lachman, "Teksty Drugie" 2009, issue 3, pp. 47-62.

Haarmann Hermann, Kurt Tucholsky: “Eine Treppe: Sprechen-Schreiben-Schweigen”, in: H. Haarmann, E. Schütz, K. Siebenhaar, B. Sösemann, Berliner Profile, Fannei \& Walz, Berlin 1993.

Haarmann Hermann, Schütz Erhard, Siebenhaar Klaus, Sösemann Berndt, Berliner Profile, Fannei \& Walz, Berlin 1993.

Hackert Fritz, Wo ist man zu Hause? Vom Unbehagen und vom Harmoniegefühl des Kurt Tucholsky, in: Halb erotisch - halb politisch. Kabarett und Freundschaft bei Kurt Tucholsky, S. Oswalt (ed.), BI S, Oldenburg 2000.

Halb erotisch - halb politisch. Kabarett und Freundschaft bei Kurt Tucholsky, S. Oswalt (ed.), BI S, Oldenburg 2000.

Hepp Michael, "Dieser Jude Tucholsky hat Deutschland, hat Westeuropa noch manches zu sagen”. Einführung zur Tagung, in: Kurt Tucholsky und das Judentum, M. Hepp, in cooperation with:K. Erwentraut, R. Links (eds.), Bibliotheks- und Informtionssystem der Universität Oldenburg, Oldenburg 1996. 
Hepp Michael, Kurt Tucholsky, ed. 3, Rowohlt, Reinbek 2004.

Ignaczak Lidia, Tuwimowski romans z piosenka, in: Julian Tuwim. Biografia. Twórczość. Recepcja, K. Ratajska, T. Cieślak (eds.), Wydawnictwo Uniwersytetu Lódzkiego, Lodz 2007.

Jäger Michael, Autobiographie und Geschichte. Wilhelm Dilthey, Georg Misch, Karl Löwith, Gottfried Benn, Alfred Döblin, J.B. Metzler, Stuttgart 1995.

Julian Tuwim. Biografia. Twórczość. Recepcja, K. Ratajska, T. Cieślak (eds.), Wydawnictwo Uniwersytetu Łódzkiego, Lodz 2007.

Kiesel Helmuth, Alfred Döblins Verhältnis zum Judentum, in: Alfred Döblin - Judentum und Katholizismus, K. Sauerland (ed.), Duncker \& Humblot, Berlin 2010.

Kowalska Hanna, Problem tożsamości narodowej w twórczości Juliana Tuwima, in: Pisarze polsko-żydowscy XX wieku. Przybliżenia, M. Dą̧browski, A. Molisak (eds.), Dom Wydawniczy Elipsa, Warsaw 2006.

Krukowski Kazimierz, Moja Warszawka, Filmowa Agencja Wydawnicza, Warsaw 1957.

Kuligowska-Korzeniewska Anna, Roch Pekiński w "Różowym Stoniu” - estradowe wystapienia Juliana Tuwima w Łodzi podczas Wielkiej Wojny, in: Julian Tuwim. Biografia. Twórczość. Recepcja, K. Ratajska, T. Cieślak (eds.), Wydawnictwo Uniwersytetu Łódzkiego, Lodz 2007. Kunert Günter, Wenn Herr Wendriner noch lebte..., in: Tucholsky heute. Rückblick und Ausblick, I. Ackermann, K. Hübner (eds.), Iudicium, München 1991.

Kurt Tucholsky und das Judentum, M. Hepp, in cooperation with: K. Erwentraut, R. Links (eds.), Bibliotheks-und Informtionssystem der Universität Oldenburg, Oldenburg 1996.

Kühn Volker, Eine unglückliche Liebe. Kurt Tucholsky und das Kabarett, in: Halb erotisch - halbpolitisch. Kabarett und Freundschaft bei Kurt Tucholsky, S. Oswalt (ed.), BI S, Oldenburg 2000.

Landau-Czajka Anna, “Syn będzie Lech...”. Asymilacja Żydów w Polsce międzywojennej, Wydawnictwo Neriton \& Instytut Historii PAN, Warsaw 2006.

Lämmert Eberhard, "Sie haben alles gesehen...”. Tucholskys Warnungen vor dem Nationalsozialismus, in: Tucholsky heute. Rückblick und Ausblick, I. Ackermann, K. Hübner (eds.), Iudicium, München 1991.

Literarische Moderne, R. Grimminger, J. Murašov, J. Stückrath (eds.), Rowohlt, Reinbek 1995.

Luba Iwona, Berlin. Szalone lata dwudzieste, nocne życie i sztuka, Carta Blanca, Warsaw 2013.

Lüth Paul, Alfred Döblin als Arzt und Patient, Hippokrates Verlag, Stuttgart 1985.

Madajczyk Czesław, Klerk czy intelektualista zaangażowany? Świat polityki wobec twórców kultury i naukowców europejskich w pierwszej połowie XX wieku. Panorama, Wydawnictwo Poznańskie, Poznan 1999.

Makles Tadeusz, Wobec ojczyzn. O ojczyznach ziemskich i idealnych w twórczości Juliana Tuwimai Antoniego Stonimskiego, Wydawnictwo Uniwersytetu Śląskiego, Katowice 1987.

Marianowicz Antoni, Plamy na słoneczku. Wiersze, utwory estradowe szopki, parodie, fraszki, humoreski, przekłady 1945-1956, PIW, Warsaw 1957.

Matywiecki Piotr, Twarz Tuwima, W.A.B., Warsaw 2007.

Mayer Hans, Außenseiter, Suhrkamp, Frankfurt 1975.

Mayer Hans, Odmieńcy, translated by A. Kryczyńska, Muza, Warsaw 2005.

Meyer Jochen, Bonitz Antje, "Entlaufene Bürger". Kurt Tucholsky und die Seinen, Deutsche Schillergesellschaft, Marbach 1990.

Niemiecka satyra antyfaszystowska, compilation by A. Marianowicz, E.J. Osmańczyk, Czytelnik, Warsaw 1951. 
Phelan Tony, Mythologie und Allegorie. Selbstverständnis und satirische Strategie bei Kurt Tucholsky, in: Das literarische Leben in der Weimarer Republik, K. Bullivant (ed.), Cornelsen Verlag Scripto, Königstein 1978.

Pisarze polsko-żydowscy XX wieku. Przybliżenia, M. Dąbrowski, A. Molisak, Dom Wydawniczy Elipsa, Warsaw 2006.

Prokop-Janiec Eugenia, Literatura i nacjonalizm, Universitas, Cracow 2004.

Reich-Ranicki Marcel, Sieben Wegbereiter. Schriftsteller des zwanzigsten Jahrhunderts, DVA, München 2002.

Riha Karl, Moritat, Bänkelsang, Protestballade. Kabarett-Lyrik und engagiertes Lied in Deutschland, ed. 2, reviewed and extended., Athenäum, Königstein 1979.

Rybicka Elżbieta, Modernizowanie miasta. Zarys problematyki urbanistycznej w nowoczesnej literaturze polskiej, Universitas, Cracow 2003.

Sandauer Artur, O sytuacji pisarza polskiego pochodzenia żydowskiego w XX wieku: rzecz, która nie ja powinienem byt napisać, Czytelnik, Warsaw 1982.

Sartre Jean-Paul, Rozważania o kwestii żydowskiej, przeł. J. Lisowski, Futura Press, Warsaw 1992. Sawicka Jadwiga, Julian Tuwim, Wiedza Powszechna, Warsaw 1986.

Scherer Herbert, Individuum und Kollektv in Döblins Roman "Berlin Alexanderplatz", in: Das literarische Leben in der Weimarer Republik, K. Bullivant (ed.), Cornelsen Verlag Scripto, Königstein 1978.

Schilling Heinz, Kleinbürger. Mentalität und Lebensstil, Campus, Frankfurt a.M. 2003.

Schneider Falko, Filmpalast, Varieté, Dichterzirkel. Massenkultur und literarische Elite in der Weimarer Republik, in: Literarische Moderne, R. Grimminger, J. Murašov, J. Stückrath, Rowohlt (eds.), Reinbek 1995.

Scholler Wilfried. F., Alfred Döblin. Eine Biographie, Carl Hanser Verlag, München 2011.

Schütz Hans J. Juden in der deutschen Literatur. Eine deutsch-jüdische Literaturgeschichte im Überblick, Piper, München-Zürich 1992.

Sidowska Karolina, Obraz kobiety w poezji Juliana Tuwima, in: Julian Tuwim. Biografia. Twórczość. Recepcja, K. Ratajska, T. Cieślak (eds.), Wydawnictwo Uniwersytetu Łódzkiego, Lodz 2007.

Stefano Giovanni di, Die monologe des Herrn Wendriner - ein Fall von jüdischem Selbsthass?, in: Kurt Tucholsky und das Judentum, M. Hepp, in cooperation with: K. Erwentraut, R. Links (eds.), Bibliotheks- und Informtionssystem der Universität Oldenburg, Oldenburg 1996.

Stępień Tomasz, Kabaret Juliana Tuwima, Wydawnictwo "Śląsk“, Katowice 1989.

Tucholsky Kurt, Gesamtausgabe. Texte und Briefe, vol. 1-22, compilation by A. Bonitz, D. Grathoff, M. Hepp, G. Kraiker et al., Rowohlt Verlag, Reinbek 1995-2011.

Tucholsky Kurt, Księga pięciu szyderców, translated by J. Frühling, A. Dołęgowski, compilation and preface by A. Marianowicz, Czytelnik, Warsaw 1955.

Tucholsky Kurt, Zamek Gripsholm, translated by Z. Fonferko, PIW, Warsaw 1986.

Tucholsky heute. Rückblick und Ausblick, I. Ackermann, K. Hübner (eds.), Iudicium, München 1991.

Tuwim Julian, Dzieła, vol. I-V, J.W. Gomulicki, S. Pollak, J. Stradecki (eds.), Czytelnik, Warsaw 1955-1964.

Tuwim Julian, My, Żydzi polscy... (We Polish Jews...), compilation and preface by Ch. Szmeruk, Fundacja Shalom, Warsaw 1993.

Tuwim Julian, Wiersze wybrane, compilation by M. Głowiński, Ossolineum, Wroclaw 1969. 
Urbanek Mariusz, Tuwim. Wylękniony bluźnierca, Wydawnictwo Iskry, Warsaw 2013.

Volkov Shulamit, Pomyst na nowoczesność. Żydzi niemieccy w XIX i na poczatku XX w., translated by J. Górny, P. Pieńkowska, Wiedza Powszechna, Warsaw 2006.

Vondung Klaus, Die Apokalypse in Deutschland, dtv, München 1988.

Voss Dietmar, Ströme und Steine. Studien zur symbolischen Textur des Werkes von Alfred Döblin,

Königshausen u. Neumann, Würzburg 2000.

Wittlin Józef, Śmierć Tuwima, in: Orfeusz w piekle XX wieku, Instytut Literacki, Paris 1963.

\section{Monika Bednarczuk}

\section{Modernity and the Jewish Stigma. Biography and Work of Julian Tuwim, Alfred Döblin and Kurt Tucholsky}

\section{(Summary)}

The paper deals with biographical, ideological and artistic links between Julian Tuwim, Alfred Döblin and Kurt Tucholsky. On the one hand, the basis of comparison are biographical similarities, the Jewish origin of those three writers, their family dramas, the experience of politically opressive school, the trauma of revolution or war, and the exile to name just a few. On the other hand, the article demonstrates the ways the modernity has influenced the attitudes and texts of Döblin, Tucholsky and Tuwim. While talking about modernity, the author focuses on such phenomena as secularisation and urbanisation processes, mass political movements, and new cultural challenges.

Tuwim, Döblin and Tucholsky were born into assimilated Jewish families. Their perspective on the stereotypical Jews (the orthodox Jews as well as Jewish bankers or manufacturers) is marked with antipathy, or even contempt. The writers' ambivalence towards the diapora and towards their own origin illustrate "Jewish self-hatred"; however, all three authors change their opinion on Jewry in the face of the growing anti-Semitic and Nazi danger, and especially the Holocaust. Döblin is proud of being Jewish after his visit to Poland in 1924, Tucholsky warns German Jews against the consequences of their passivitivy, and Tuwim publishes in 1944 his agitating manifesto We, Polish Jews. Last but not least, the three authors go into exile because of their Jewish ancestry and sociocultural activities. Therefore, it is no coincidence thatone cannot help having associations with Heinrich Heine: his biography can be interpreted as a prefiguration of a Jewish artist's biography.

Furthermore, Tuwim, Döblin and Tucholsky are notably sensitive to social questions, and their sensitivity to such issues results to some extent from their difficult childhood and youth. Especially significant seem in that respect family conflicts and the moving from city to city, since such experiences increase the feeling of loneliness and the vulnerability to depression. Nevertheless, Döblin, Tucholsky and Tuwim come with impetus into the cultural life of Germany and Poland and work in the areas of literature, cabaret (satire) as well as journalism. They share sympathy for the political left and fears of the orthodox communism. They are simultaneously advocates and ardent critics of great cities. They pay attention to new phenomena (the popularity of cars, the role of the press, the new morality) and react to them. Their aim is creating a culture which appeals to the masses and educates them in a non-intrusive way. However, the awareness of their own intellectual superiority imposes distance towards lower social groups. The distance stems, firstly, 
from the universal ambivalence artists feel towards the masses, and secondly, from the ideological moderation characteristic of petit bourgoisie and of the political centre. In general, Döblin, Tucholsky and Tuwim are idealists who hope for a humanitarian world which is impossible in the era of extrem political violence leading to the Holocaust.

Keywords: Julian Tuwim, Alfred Döblin, Kurt Tucholsky, comparative studies, modernity, city, mass culture, Jewish identity, asimilation, alienation 